Univerzitet u Beogradu
Poljoprivredni fakultet
Institut za poljoprivrednu tehniku
Naučni časopis
POLJOPRIVREDNA TEHNIKA
Godina XLIII
Broj 3, 2018.
Strane: $38-44$

\title{
MANAGEMENT SERVICES WITH RESPECT TO THE NEW APPROACH PVC PACKAGING IN THE AGRICULTURAL ENTERPRISES WITH AGRO-ECOLOGICAL ASPECTS
}

\author{
Popović Slobodan*1, Laban Bogdan ${ }^{2}$, Popović Vera ${ }^{3}$, \\ Jovin Slobodanka ${ }^{4}$, Grublješić Željko ${ }^{5}$ \\ ${ }^{1}$ Assistant Professor, Department of Management and Finance, Faculty of Economics \\ and Engineering Management, Cvećarska 2, Novi Sad, Serbia, \\ ${ }^{2}$ Assistant Professor, Department of Management and Finance, Faculty of \\ Economics and Engineering Management, Cvećarska 2, Novi Sad, Serbia \\ ${ }^{3}$ Institute of Field and Vegetable Crops, Maksima Gorkog 30, Novi Sad, Srbija, \\ ${ }^{4}$ Ph.D., Professional Studies, High Business School of Novi Sad, \\ Vladimira Perića Valtera 4, Serbia, \\ ${ }^{5}$ Assistant Professor, PIM University Banja Luka, Banja Luka, \\ Despota Stefana Lazarevića BB, Bosnia and Hercegovina.
}

\begin{abstract}
Corporate management demands new ways to improve business. In the paper the author's focus was on the application of PVC packaging from the agroecological aspect. Comparison of the number of weed weeds in compost that was stored outdoors in relation to the number of weed weeds in compost kept in plastic containers was performed. The experiment was carried out on 10x10 cm plain surfaces of both composts in real nursery production in a large nursery in Novi Sad. Changes were found that indicate differences in the number of weed weeds on all parcels covered with compost that was differently conserved. The obtained average results of the weed plants at the end of the first week on the parcels amounted to the first compost 1.6 and higher compared to 0.9 in the second mode of storage at the end of the second week at 2.8 at 1.4 and at the end of the third week 5.5 compared to 1.1 for composts stored in PVC packaging. PVC packaging can be reused in more than 10 new cycles in nursery production and overall results point to the overall positive trend of such compost storage.
\end{abstract}

Keywords: compost, PVC, nursery production.

\footnotetext{
*Kontakt autor. E-mail adresa: slobodan.popovic49@gmail.com.
} 


\section{INTRODUCTION}

A new approach to managing the economy of the Republic of Serbia is based on economic development, where agricultural production has its important place. More and more authors observe multidisciplinary processes, for example in agriculture, observation is made in the context of socio-economic processes [1], but the observation is made from the ecological [2], technical technological and others.

Socially responsible behavior, especially enterprises, greatly facilitates the rapid development of information technology [3]. In transition economies, are beginning to observe and question the "green economy" can be seen in the works of many authors [4], [5], [6], [7]. However we should not forget that the planning of economic activity is the primary stage of process management in the whole economy, but it should not forget the importance of the market environment [8].

The process of economic activity should be considered a long-term [9], and that is of great importance to the existence of the constructed information system [10], and after the economic activity of all activities of the company are subject to verification and Auditing [11], [12], [13].

Accordingly, except in this way observed the general approach it is important to emphasize the existence of new approaches in agricultural production. Thus modern agriculture needs to seek new approaches to solving the problems standing in front of her; one of these solutions is a maximum consideration of complex ecological approach, as we see in the works [14], [15], [16], [17], [18]. One such approach authors presented in this paper.

Only observation and presentation was made on the basis of experiments with compost in real terms. The aim is to point out the importance of proper and a new approach to storage of produced compost. Results of this study indicate that there is more positivity in the case of application of compost storage in plastic containers before planting annual plants in nursery production.

The main results point to big savings in labor and time needed to create favorable conditions for raising plants in the first phase of forming the same. But beyond these basic results are the results of that plastic packaging can be reused for storing compost (previous studies suggest the use of more than 10 times in the same packaging).

\section{MATERIAL AND METHODS}

To make this work the authors have carried out experimental measurements within the nursery public utility company, the second largest in Serbia, which among other things deals with the maintenance of green areas, nursery production one year of flowers and other plant species. The results are verifiable and can be used for new research to determine the optimal use of packaging, storage, compost and others.

The aforementioned public utility company, whose name is not stated, independently produced compost from plant residues obtained from the area of the wider area of Novi Sad. Production is carried out in the open, under the full influence of natural factors on the biomass without the use of additives and other accelerators. 
The only use of machinery is turning occasionally plant mass that produces compost, a measure of production optimization is performed periodically irrigation in the summer months, when there is not enough rainfall.

Compost that is obtained is aged 1.5-2 years from the time of grinding plant mass. Exposed is the existence of 50-200 m borders with parcels on which there are weed surface, and the same smooth or partially smooth may affect the contamination seed weeds on the parcel under the compost.

During 2015-2017 compost is stored in individual containers of PVC, which is closed in an open warehouse, and the same packaging is re-used during less than two years and more than 10 times without a problem. The basic rate is only careful handling with bags to avoid mechanical damage. Thus, the same package can be used in multiple cycles, thereby reducing the cost of the same, a saving is achieved, and in the manipulation of the compost to the moment of planting the perennial plant species.

\section{RESULTS AND DISCUSSION}

The experiment was carried out within the nursery and it was carried out on five pitches in size $10 \times 10 \mathrm{~cm}$ and the same number of control by the same plot, the surface of which is neatly bay and that is used for regular production plant species. The same experiment was repeated performed in the first three weeks after putting compost in land parcels nursery. Besides the three times was committed measurement, on days in the period from 12.06.2017 to 26.06.2017. With the basic aim of counting the plants sprouted weeds in the compost heap, to later compare the data with compost which is stored in plastic. Packaging 30-60 days prior to use in the production of compost.

The authors give an overview in the form of table 1 . The obtained results of measurements of seedlings, weed compost, which is taken from the fields where it is produced, predominantly perennial crops.

Table 1. Results of measurement for given measurement, and the number of seedlings of weeds in the plots and the control plots nursery

\begin{tabular}{|c|c|c|c|c|c|c|}
\hline \multirow[t]{3}{*}{ Trial plot } & \multicolumn{6}{|c|}{ Results of measurements per day } \\
\hline & \multicolumn{2}{|c|}{12.06 .2017} & \multicolumn{2}{|c|}{19.06 .2017} & \multicolumn{2}{|c|}{26.06 .2017} \\
\hline & $A$ & $B$ & Al & $B 1$ & $A 2$ & $B 2$ \\
\hline 1 & 2 & 4 & 6 & 5 & 7 & 6 \\
\hline 2 & 1 & 2 & 1 & 4 & 6 & 4 \\
\hline 3 & 4 & 1 & 4 & 3 & 8 & 7 \\
\hline 4 & 0 & 0 & 1 & 1 & 3 & 5 \\
\hline 5 & 1 & 1 & 1 & 2 & 4 & 5 \\
\hline
\end{tabular}

Note $(\mathrm{A}=\mathrm{A} 1=\mathrm{A} 2$ and it is measured plots; $\mathrm{B}=\mathrm{B} 1=\mathrm{B} 2$ to represent the control plots $)$

To professional community acquired comparable picture of what happens to the compost is taken from real production and which is stored in plastic containers in the aforementioned one term storage in an open warehouse authors are shown in Table 2, given the survey results measuring the number of emerged weeds from compost is stored in plastic containers before planting in the nursery plots. 
Table 2. Results of measurement for given measurement, and the number of seedlings of weeds in the plots and the control plots nursery from the compost that is stored in plastic containers

\begin{tabular}{|c|c|c|c|c|c|c|}
\hline \multirow{3}{*}{ Trial plot } & \multicolumn{6}{|c|}{ Results of measurements per day } \\
\hline & \multicolumn{2}{|c|}{12.06 .2017} & \multicolumn{2}{|c|}{19.06 .2017} & \multicolumn{2}{|c|}{26.06 .2017} \\
\hline & $A$ & $B$ & Al & $B 1$ & $A 2$ & $B 2$ \\
\hline 1 & 1 & 2 & 2 & 2 & 1 & 2 \\
\hline 2 & 1 & 0 & 1 & 1 & 2 & 1 \\
\hline 3 & 3 & 1 & 3 & 2 & 1 & 1 \\
\hline 4 & 0 & 0 & 1 & 0 & 1 & 1 \\
\hline 5 & 0 & 0 & 1 & 1 & 0 & 1 \\
\hline
\end{tabular}

Note $(\mathrm{A}=\mathrm{A} 1=\mathrm{A} 2$ and it is measured plots; $\mathrm{B}=\mathrm{B} 1=\mathrm{B} 2$ to represent the control plots $)$

Based on the measurement results, the authors are using the standard methods of statistical processing device displays the average of the values obtained germinating weed plants per plot (5 standard +5 control plots), from the compost and compost, which is stored in plastic containers. These results are presented in Table 3, where the professional public can see a comparison of the results obtained.

Table 3. Results of measurement for a given measurement, and the number of seedlings of weeds in the plots and the control plots nursery from compost that was taken from the classic production of compost and one that stored in PVC packaging by the average values

\begin{tabular}{|c|c|c|c|c|c|c|}
\hline \multirow{3}{*}{ Trial plot } & \multicolumn{7}{|c|}{ Results of measurements per day } \\
\cline { 2 - 7 } & \multicolumn{2}{|c|}{12.06 .2017} & \multicolumn{2}{c|}{19.06 .2017} & \multicolumn{2}{c|}{26.06 .2017} \\
\cline { 2 - 7 } & $A$ & $B$ & $A 1$ & $B 1$ & $A 2$ & $B 2$ \\
\hline 1 & 3 & 1,5 & 5,5 & 2 & 6,5 & 1,5 \\
\hline 2 & 1,5 & 1 & 2,5 & 1 & 5 & 1,5 \\
\hline 3 & 2,5 & 2 & 3,5 & 2,5 & 7,5 & 1 \\
\hline 4 & 0 & 0 & 1 & 0,5 & 4 & 1 \\
\hline 5 & 1 & 0 & 1,5 & 1 & 4,5 & 0,5 \\
\hline
\end{tabular}

Note $(\mathrm{A}=\mathrm{A} 1=\mathrm{A} 2$ Average number of seedlings from the classical compost, $\mathrm{B}=\mathrm{B} 1=\mathrm{B} 2$ Average number of emerged plants from compost guarded in PVC packaging)

The research results show the real values obtained after experimental production with the use of plastic packaging, and can be used for making management decisions in some subsequent cycles of real business.

Authors are given in Table 4 show the average germinating weed plants for all 5 pitches and 5 control plots per day from 12/06/2017 to 06/26/2017., where we can see a clear movement and there was a trend emerged weed plants per plot in the first three weeks after putting compost in real exploitation. 
Table 4. Results of measurement for given measurement, and the number of seedlings of weeds in the plots and the control plots nursery from compost that was taken from the classic production of compost and one that stored in PVC packaging by the average values

\begin{tabular}{|l|c|c|}
\hline \multirow{2}{*}{$\begin{array}{l}\text { Date of } \\
\text { measuring the } \\
\begin{array}{l}\text { number of } \\
\text { weed species }\end{array}\end{array}$} & $\begin{array}{l}\text { Only an average of emerged plants from compost obtained by conventional } \\
\text { production and compost that is stored in plastic containers }\end{array}$ \\
\cline { 2 - 3 } & $A$ & $B$ \\
\hline 12.06 .2017 & 1,6 & 0,9 \\
\hline 19.06 .2017 & 2,8 & 1,4 \\
\hline 26.06 .2017 & 5,5 & 1,1 \\
\hline
\end{tabular}

Note $(\mathrm{A}=$ average number of average germinating plant from the classical compost on all plots and the control plots, $\mathrm{B}=$ average number of emerged plants an average of compost kept in a plastic container in all the plots and the plots were control)

The results in Table 4 clearly show that there is justification for keeping the compost obtained in real conditions of exploitation in plastic packaging. In the first week of measurement average ratio of germinated plants weeds in all plots in which the measurement is carried out on the surface of $10 \times 10 \mathrm{~cm}$ was 1,6 plants, and at the same conditions the average number of emerged weed plants from the compost, which was stored in plastic containers and were considerably smaller was 0.9 .

In the second week of this relationship is even better and to $100 \%$ reduced the number average weed plants, while in the third week of the relationship is improving and five times better results were obtained by the average number of emerged weed plants from the compost that is stored in plastic containers.

This work of authors can serve and reach significance in those companies that do not May introduced internal audit and internal control [19], [20], because in such companies there is no obligation, and the imperative of reporting on the goals of reducing management costs.

In addition, this work clearly points to the potential savings in terms of environmental protection because the packaging is no problem can be used 10 times or more, and achieve a better effect, because nobody much smaller number of weeds, which saves the labor force in terms of cultivating nursery produced plant species, the simpler the work, or economic agronomic effects are clearly visible.

Based on the previously presented results clearly it can be said that there are economic or other benefits from the implementation of some standard methods that do not will in future become even more important, because they show economic-agronomic and ecological effects that are favorable to the individual, enterprise and society as a whole.

With this work the authors point to the importance of access to different packaging, especially PVC, but the same can be replaced and other containers such as biodegradable packaging. In any case, this work can serve as a basis for future, especially in transition countries that have to reduce production costs at all levels. 


\section{CONCLUSIONS}

Nursery production in transition countries like the Republic of Serbia requires finding the most optimal processes to manufacture their products competitive in the market. One way to meet more optimality criterion is presented in this paper.

We will mention only a few: the packaging which holds the compost before planting was used more than 10 times, the careful use of the same can be used in multiple cycles of production, experimental authors gave presentations in the first three weeks after putting compost in real terms nursery production that indicate justification of use of the same, because after three weeks reduces the number of weed plants for five times.

Continuation of such research can be done to achieve a new model that will result in even greater improvements in production, especially in the first stages of production of perennial plant species.

The aim of this study was to point out the great importance of finding new models of optimization. This can be accomplished and agro-economic benefits by legal entities that make their living in the field of agro business. In addition this study may serve as the basis of new research in real conditions of productions in nursery plant a large number of small enterprises, primarily in the domain of agriculture.

\section{REFERENCES}

[1] Popović., S. 2014. Socio-ekonomski faktori ograničenja razvoja agrara, Monografija, Fimek, Novi Sad, pp. 30

[2] Popović, S., Novaković, S., Đuranović, D., Mijić, R., Grublješić, Ž., Aničić, J. \& Majstorović, A. 2017. Application of international accounting standard-16 in a public company with predominantly agricultural activities, Economic Research-Ekonomska istraživanja, Vol. 30, No. 1, pp. 1850-1864.

[3] Flecher, K. 2003. Upravljanje marketingom i IT, Klio, Beograd, pp. 27.

[4] Holcher, J. 2011. Twenty years of economic transition: Success and Failures, The Journal of competitive economic studies, pp. 15.

[5] Popović S, Jovin S, Đuranović D, Popović V, Filipović V, Munitlak-Ivanović O, Grublješić Ž, Mijić R. 2017b. The Importance of Planting Pot Marigolds (Calendula officinalis L.) in degraded public spaces from the agroecological and economic perspective. Contemporary Agriculture, 66(1-2): pp. 27-31.

[6] Ljubojević, M. 2012. The increase in poverty, transition and globalization, Fond Slobodan Jovanović, Beograd, pp. 12.

[7] Hisrich, D.R., Peters, P.M., Shepherd, A. D. 2011. Preduzetništvo, Mate, Zagreb.

[8] Greuning, H. 2006. Međunarodni standardi finansijskog izveštavanja, Mate, Beograd, p. 4.

[10] Gritsenko O.I. and Skorba O.A. 2015. Internal business control of service quality costs: managerial aspect, Actual problems of economy, 3, pp. 365-373.

[11] Panchuk P. 2015. Harmonization of accounting and taxation accounting at reporting formation on income. Actual problems of economy, pp. 373-379.

[12] Popović S. 2015. Implementacija heterogenih rizika u radu interne revizije, Revizor, 69, pp. 7-19.

[13] Popović S., Majstorović A., Grublješić Ž. 2015- Valuation of facilities in use and application of international accounting standards. Actual problems of economy, p. 379-387.

[14] Bonaca, I. And Dumitras, L. 2014. Integrated System in Landscaping Design and Landscape Ecology: Simplicity or Complexity?, ProEnvironment, pp. 46-52. 
[15] Chan, R.Y.K. And Lau, L.B.Y.. 2004. The effectiveness of environmental claims among Chinese consumers: Influences of claim type, country disposition and eccentric orientation. Journal of Marketing Management, pp. 273-319.

[16] Davis, J.J.1993. Strategies for environmental advertising, The Journal of Consumer Marketing, pp. 19-36.

[17] Dinu, V.2011. Corporate Social Responsibility - Opportunity for Reconciliation between Economical Interests and Social and Environmental Interests, Amfiteatru Economic, p. 6-7.

[18] Mihaiescu, T. 2013. Assessment of Soil Erosion Risk in Fizes River Catchment Using USLE Model and GIS, ProEnvironment 6, pp. 595-599.

[19] Popović, S. 2015. Implementacija heterogenih rizika u radu interne revizije, Revizor, No. 69, pp.7-19.

[20] Popović, S. 2015. Interna revizija kao pokretač finansijske analize u javnim preduzećima RS, Revizor, 72, pp. 41-53.

\title{
UPRAVLJANJE KORIŠTENJEM NOVOG NAČINA PVC PAKOVANJA U POLJOPRIVREDNIM PREDUZEĆIMA SA AGRO-EKOLOŠKIM ASPEKTIMA
}

\author{
Popović Slobodan ${ }^{1}$, Laban Bogdan ${ }^{2}$, Popović Vera ${ }^{3}$, \\ Jovin Slobodanka ${ }^{4}$, Grublješić Željko
}

${ }^{l}$ Docent, Fakultet za ekonomiju i industrijski menadžment, Cvećarska 2, N. Sad, Srbija

${ }^{2}$ Docent, Fakultet za ekonomiju i industrijski menadžment, Cvećarska 2, N. Sad, Srbija

${ }^{3}$ Institut za ratarstvo i povrtarstvo, Maksima Gorkog 30, Novi Sad, Srbija

${ }^{4}$ Visoka poslovna škola, Vladimira Perića Valtera 4, Novi Sad, Srbija

${ }^{5}$ Docent, Univerzitet za poslovni inžinjering i menadžment, Banja Luka, Despota Stefana Lazarevića bb, BiH.

Sažetak: Korporativno upravljanje zahteva nove načine unapređenja poslovanja. U radu fokus autora bio je usmeren na primenu PVC ambalaže sa agro-ekološkog aspekta. Izvršena je komparacija broja izniklih korovskih biljaka kod komposta koji je skladišten na otvorenom $\mathrm{u}$ odnosu na broj korovskih biljaka kod komposta koji je čuvan $\mathrm{u}$ plastičnim kontejnerima. Eksperiment je urađen na površinama $10 \times 10 \mathrm{~cm}$ redno postavljenom površinom sa oba komposta u rasadničkoj proizvodnji u velikom rasadniku u Novom Sadu. Utvrđene su promene koje ukazuju na razlike broja korovskih biljaka na svim parcelama koje su prekrivene kompostom koji je različito bio čuvan. Dobijeni prosečni rezultati broja korovskih biljaka na kraju prve nedelje na parcelama iznose kod prvog načina čuvanja komposta 1.6 i veći su u poređenju sa 0.9 kod drugog načina čuvanja, na kraju druge nedelje iznose 2.8 u poređenju sa 1.4 , a na kraju treće nedelje iznose 5.5 u odnosu na 1.1 kod komposta čuvanog u PVC ambalaži. PVC ambalaža može se ponovo koristiti u više od 10 novih ciklusa u rasadničkoj proizvodnji, a generalno rezultati ukazuju na pozitivan trend takvog načina skladištenja komposta.

Ključne reči: Kompost, PVC ambalaža, poboljšanja proizvodnje.

Prijavljen: $\quad 08.08 .2018$

Ispravljen: $\quad 01.09 .2018$

Prihvaćen: $\quad 10.09 .2018$ 